\title{
Coccolithophores from the central Arabian Sea: Sediment trap results
}

\author{
Lina P MergulhaO ${ }^{1, *}$, Rahul Mohan ${ }^{2}, \mathrm{~V} \mathrm{~S} \mathrm{~N} \mathrm{Murty}^{1}, \mathrm{M} \mathrm{V} \mathrm{S} \mathrm{Guptha}^{1,3}$ and D K Sinha ${ }^{4}$ \\ ${ }^{1}$ National Institute of Oceanography, Dona Paula, Goa 403 004, India. \\ ${ }^{2}$ National Centre for Antarctic and Ocean Research, Headland Sada, Vasco-da-Gama, Goa 403 804, India. \\ ${ }^{3}$ Present address: 62, Sagar Society, Dona Paula, Goa 403 004, India. \\ ${ }^{4}$ Department of Geology, Banaras Hindu University, Varanasi 221 005, India. \\ *e-mail: mlina@rediffmail.com
}

\begin{abstract}
Sediment trap samples collected from a depth of $1018 \mathrm{~m}$ in the Central Arabian Sea Trap (CAST) at $14^{\circ} 28.2^{\prime} \mathrm{N}, 64^{\circ} 35.8^{\prime} \mathrm{E}$ were analyzed for temporal variation of coccolithophore fluxes from October 1993 to August 1994. Out of the twenty species of coccolithophores encountered, Gephyrocapsa oceanica, Emiliania huxleyi, Umbilicosphaera sibogae and Umbellosphaera irregularis were the most abundant. The total coccolithophore fluxes ranged from $28.5 \times 10^{6} \mathrm{~m}^{-2} \mathrm{~d}^{-1}$ to $50.3 \times 10^{6} \mathrm{~m}^{-2} \mathrm{~d}^{-1}$ showing seasonality with higher fluxes during the northeast (NE) monsoon and lower fluxes during the spring intermonsoon. The higher fluxes were attributed to the enhancement of primary production in the central Arabian Sea due to southward extent of nutrients from the northeast Arabian Sea by the prevailing surface currents. Similarly, the occurrences of relatively lower coccolithophore fluxes during the spring intermonsoon and southwest (SW) monsoon were attributed to the low nutrients in the warm, shallow surface mixed layer and downwelling to the south of Findlater Jet respectively in the central Arabian Sea. Some of the coccolithophore species such as E. huxleyi, G. oceanica, Calcidiscus leptoporus and Umbellosphaera tenuis showed signs of dissolution.
\end{abstract}

\section{Introduction}

Coccolithophores are one of the major primary producers and one of the most important groups, of microplankton contributing to the phytoplankton community in the oceans. Generally, the coccolithophores dominate in the stratified waters of the tropical and subtropical regions (Brand 1994). However, there have been many reports on their abundant occurrences within the mixed layer (Kleijne 1993; Giraudeau et al 1993). The coccolithophores are useful to interpret the hydrographic conditions and the extent of primary productivity in the study regions. These coccolithophores convert dissolved carbon dioxide in the ocean into calcium carbonate $\left(\mathrm{CaCO}_{3}\right)$. The pathway from production of this mineral at the sea surface to its deposition on the sea floor is an important process and is an essential variable in the global carbon cycle (Broerse et al 2000; Ziveri et al 2000). Coccolithophores are also known to influence the global climate through emission of dimethylsulphide (Westbroeck et al 1993). Owing to the fact that the mass of a single coccolith is about $8 \times 10^{-6} \mu \mathrm{g}$ with a surface area of $32 \mu \mathrm{m}^{2}$ and settling velocity of $1.6 \mu \mathrm{m} / \mathrm{s}$ (or $13.8 \mathrm{~cm} / \mathrm{d}$ ), the sedimentation to the ocean floor is a complex process (Steinmetz 1994). Therefore, the slow descent rate and large area of a coccolith increases its residence period in the water column resulting in rapid dissolution of coccolithophores (Honjo 1975; Steinmetz 1994). However, fecal pellets and other oceanic macroaggregates are the main carriers for the rapid vertical transport of

Keywords. Coccolithophores; central Arabian Sea; sediment trap; monsoon; upwelling and dissolution. 
the majority of coccolithophores through undersaturated waters to the sea-floor (Honjo 1975, 1980). The typical sinking speeds of larger particles are of the order of 100 to $200 \mathrm{~m} / \mathrm{d}$ (Waniek et al 2000). Understanding the export of living coccolithophore assemblages and their ecological significance as they sink from the euphotic zone to the seafloor are essential in the studies of paleoceanography and paleoclimate. Earlier studies on coccolithophores from the Arabian Sea were largely confined to the sediment (Andruleit and Rogalla 2002). However, Kleijne (1993); Guptha et al (1995); Zeltner (1998); Andruleit et al (2000, 2003) and Schiebel et al (2004) studied living flora from water samples. Subsequent studies on coccolithophores using sediment trap samples were limited to the northwestern Arabian Sea (June 1992-February 1993) by Broerse et al (2000) and northeastern Arabian Sea (October 1993-February 1994 and May 1995-February 1996) by Andruleit et al (2000). In this context, the present study is focused on the sediment trap samples collected from the central Arabian Sea to understand the living coccolithophores and their ecological implications in relation to the semi-annually reversing monsoons and the associated hydrographic conditions.

\section{Hydrography of the central Arabian Sea}

The Arabian Sea falls under the influence of semiannually reversing monsoons - the northeast (NE) monsoon (winter monsoon) during NovemberFebruary and the southwest (SW) monsoon (summer monsoon) during June-September. These semi-annual monsoon winds drive strong surface currents and the associated upper layer circulation reverses with season (Wyrtki 1973; Mariano et al 1995; Shankar et al 2002). The seasonal surface drift currents (Mariano et al 1995) during January and July (figure 1a-b), representing the NE and SW monsoons respectively, show a southwestward flow towards the central Arabian Sea (study area) from the northeast coast of India in January and an eastward flow emanating from the western Arabian Sea towards central Arabian Sea in July. During SW monsoon, the low-level Findlater Jet (Findlater 1969) with high intensity of southwesterly winds crosses over central Arabian Sea in the SW-NE direction (Madhupratap et al 1996; Manghnani et al 1998; Prasanna Kumar et al 2001a), i.e., north of the sediment trap location at $14^{\circ} \mathrm{N}$ (shown by solid square in figure $1 \mathrm{a}$ and $1 \mathrm{~b}$ ). Under the influence of the Findlater Jet, surface winds are strong over the central Arabian Sea, which in turn plays a vital role in the

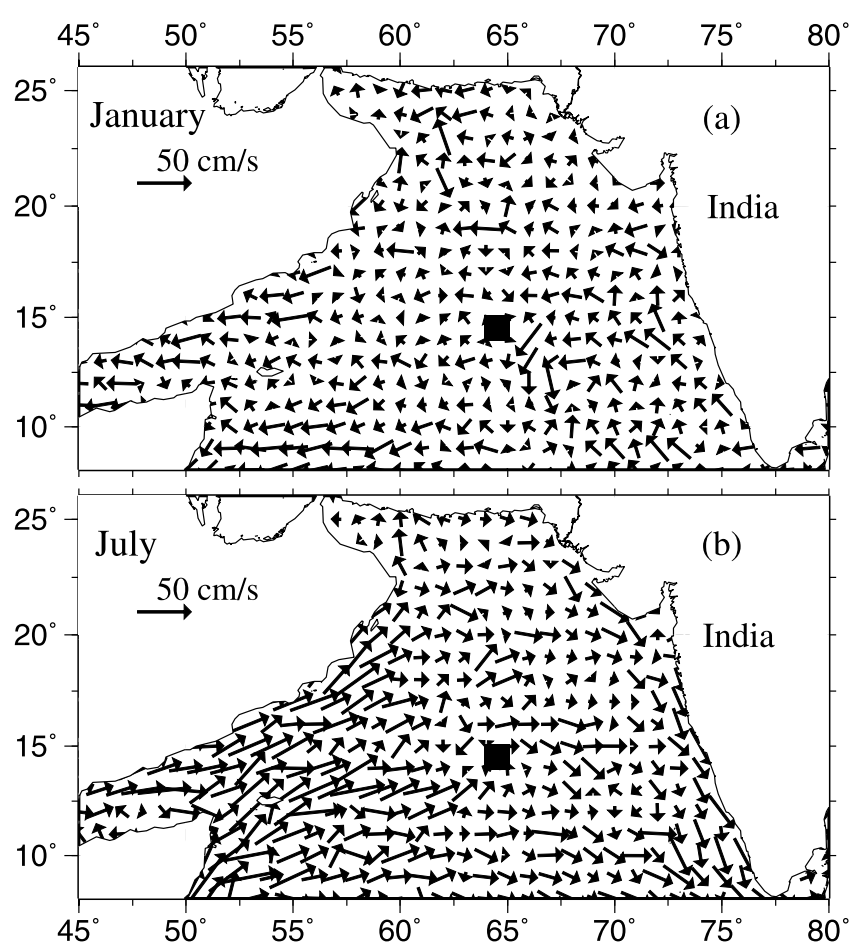

Figure 1. Surface current vectors derived from ship drifts in the Arabian Sea during (a) January and (b) July. (After Mariano et al 1995.) The sediment trap location is depicted as a solid square.

oceanic and air-sea interaction processes (Flagg and Kim 1998; Manghnani et al 1998; Morrison et al 1998; Prasanna Kumar and Narvekar 2005). Morrison et al (1998) reported seasonal variation of sea surface temperature, sea surface salinity, mixed layer depth, subsurface water masses and inorganic nitrogen (nitrate + nitrite + nitrogen) for the period between September 1994 and December 1995 in the Arabian Sea. Furthermore, they have shown that a large part of central Arabian Sea exhibits a deep mixed layer $(100-120 \mathrm{~m})$ and elevated concentration of nitrates during both the NE and SW monsoons. Winter cooling at the sea surface due to enhanced evaporation and decrease in solar radiation caused deepening of the mixed layer and an elevation of nutrients by entrainment within the upper oceanic layer (Prasanna Kumar and Prasad 1996; Morrison et al 1998). During SW monsoon, concentration of inorganic nitrogen (mostly nitrates) was high in the upwelling zone off Oman and decreased towards the central Arabian Sea, which was, however, relatively high compared to the eastern Arabian Sea (Morrison et al 1998). Prasanna Kumar and Narvekar (2005) discussed seasonal variability of mixed layer depth as a result of wind forcing and its implication to the variability of nutrients, chlorophyll- $a$ and primary productivity in the central Arabian Sea along $64^{\circ} \mathrm{E}$ section and inferred prevalence of intense upwelling to the north of the Findlater Jet axis 
and downwelling to its south (Prasanna Kumar et al 2001b; Prasanna Kumar and Narvekar 2005 and the relevant references therein) during SW monsoon. They further reported higher concentration of nitrate $(1 \mu \mathrm{M})$ at shallow depths $(20 \mathrm{~m})$ with higher surface chlorophyll- $a\left(1.0 \mathrm{mg} / \mathrm{m}^{3}\right)$ to the north of the Jet axis $\left(17^{\circ} \mathrm{N}-19^{\circ} \mathrm{N}\right)$. During NE monsoon the cold and dry winds from the northeast induce increased cooling of surface waters near the Gulf of Oman and along the Pakistan shelf leading to intense wind mixing and the associated entrainment results in higher nitrate concentration $(1-3 \mu \mathrm{M})$ in the surface layer north of $15^{\circ} \mathrm{N}$, along with elevated surface chlorophyll$a$ leading to high biological productivity (Qasim 1982; Smith et al 1991; Madhupratap et al 1996; Prasanna Kumar et al 2000). During spring intermonsoon (March-May), the mixed layer depth is shallow $(\sim 30 \mathrm{~m})$ due to thermal stratification because of higher sea surface temperatures and intense solar radiation (Prasanna Kumar and Narvekar 2005). These authors also found low concentrations of chlorophyll- $a$ and depleted nutrients in the upper layer, suggesting the prevalence of oligotrophic conditions in the central Arabian Sea during spring intermonsoon (Morrison et al 1998). Compared to SW monsoon, surface circulation is less vigorous during $\mathrm{NE}$ monsoon and wind-induced mixing ventilates only the top of the oxygen minimum zone (Madhupratap et al 1996; Morrison et al 1998). The US JGOFS measurements showed higher primary productivity both during $\mathrm{NE}$ monsoon $\left(1-2 \mathrm{gCm}^{-2} \mathrm{~d}^{-1}\right)$ and SW monsoon $\left(1.5 \mathrm{gCm}^{-2} \mathrm{~d}^{-1}\right)$ periods (Smith et al 1998).

\section{Material and methods}

As part of the Indo-German collaborative program, a cruise onboard ORV Sagar Kanya (SK-98) was organized to deploy Mark VI time series sediment trap mooring in the central Arabian Sea $\left(14^{\circ} 28.2^{\prime} \mathrm{N}: 64^{\circ} 35.8^{\prime} \mathrm{E}\right)$ at $1018 \mathrm{~m}$ in a water column of $3914 \mathrm{~m}$ (figure 1). The sampling period was scheduled for 18 October 1993 to 5 October 1994 with sampling intervals of 27 days. Prior to the deployment, sampling cups were filled with in situ seawater collected from the trap depth to which $35 \mathrm{~g} / 1 \mathrm{NaCl}$ and $3.3 \mathrm{~g} / 1 \mathrm{HgCl}_{2}$ were added for preservation and poisoning to prevent biodegradation. Immediately after recovery, these samples were stored in cold storage at $4^{\circ} \mathrm{C}$. The supernatant solution was decanted and the residue was wet sieved through a $>1 \mathrm{~mm}$ mesh sieve, the fraction $<1 \mathrm{~mm}$ was then split into aliquot of $1 / 4$ to $1 / 18$ of the total sample volume. The samples were then filtered onto pre-weighed nucleopore filters
$(0.4 \mu \mathrm{m})$ and dried at $45^{\circ} \mathrm{C}$. A small portion of the dried filter was cut and placed on a sample stub, coated with gold/palladium (100 $\AA$ ) in a sputter coater and scanned using Joel SEM Model 5800 LV, for coccolithophore species identification and quantification. Utmost care was taken to ensure that the particles were distributed in a monolayer on the filter. The number of coccospheres and coccoliths were then counted at a higher magnification of 3500 for 15-20 fields of view with a minimum count of 350-800 cells depending on their availability. Total cocolithophore (coccolith and coccosphere) fluxes $\left(\times \mathrm{Nos} / \mathrm{m}^{2} /\right.$ day $)$ were calculated by extrapolating the counted specimens for the total sample, duration of trap and aperture area.

The $\mathrm{CaCO}_{3}$ flux of coccolith was estimated by multiplying the specific weight of each coccolith species by their corresponding fluxes (Broerse et al 2000). Similarly, $\mathrm{CaCO}_{3}$ flux of coccospheres was also estimated by multiplying the coccosphere fluxes by the mean number of coccoliths and their specific coccolith weight (Broerse et al 2000).

\section{Results}

This study yielded twenty species of coccolithophores with a total flux of coccoliths ranging from $28.5 \times 10^{6} \mathrm{~m}^{-2} \mathrm{~d}^{-1}$ to $50.3 \times 10^{6} \mathrm{~m}^{-2} \mathrm{~d}^{-1}$ (tables 1 and 2). Among them, Gephyrocapsa oceanica, Emiliania huxleyi, Umbilicosphaera sibogae and Umbellosphaera irregularis were by far the most abundant, followed by less abundant species viz., Coronosphaera mediterranea, Helicosphaera carteri, Calcidiscus leptoporus, Florisphaera profunda, Anoplosolenia braciliensisi, Calciosolenia murrayi and Oolithotus antillarum. Minor species such as Discosphaera tubifera, Syracosphaera pulchra, Umbellosphaera tenuis, Neosphaera coccolithomorpha, Algirosphaera oryza, Michaelsarsia adriaticus, Gladiolithus flabellatus and Rhabdosphaera clavigera were also observed. Although 20 species were identified, the distribution patterns of only four dominant species along with moderately represented species (Helicosphaera carteri, Calcidiscus leptoporus, Florisphaera profunda, Oolithotus antillarum) are presented (figure $2 \mathrm{a}-\mathrm{b}$ ). In addition to the majority of isolated coccoliths, a few coccospheres comprising of $G$. oceanica, E. huxleyi, G. flabellatus, A. oryza, F. profunda, C. leptoporus were also observed in association with a few diatoms and silicoflagellates.

Total fluxes of coccolithophores displayed seasonality with highest fluxes $\left(50.6 \times 10^{6} \mathrm{~m}^{-2} \mathrm{~d}^{-1}\right)$ occurring during NE monsoon (7 January3 March 1994) and relatively high fluxes 


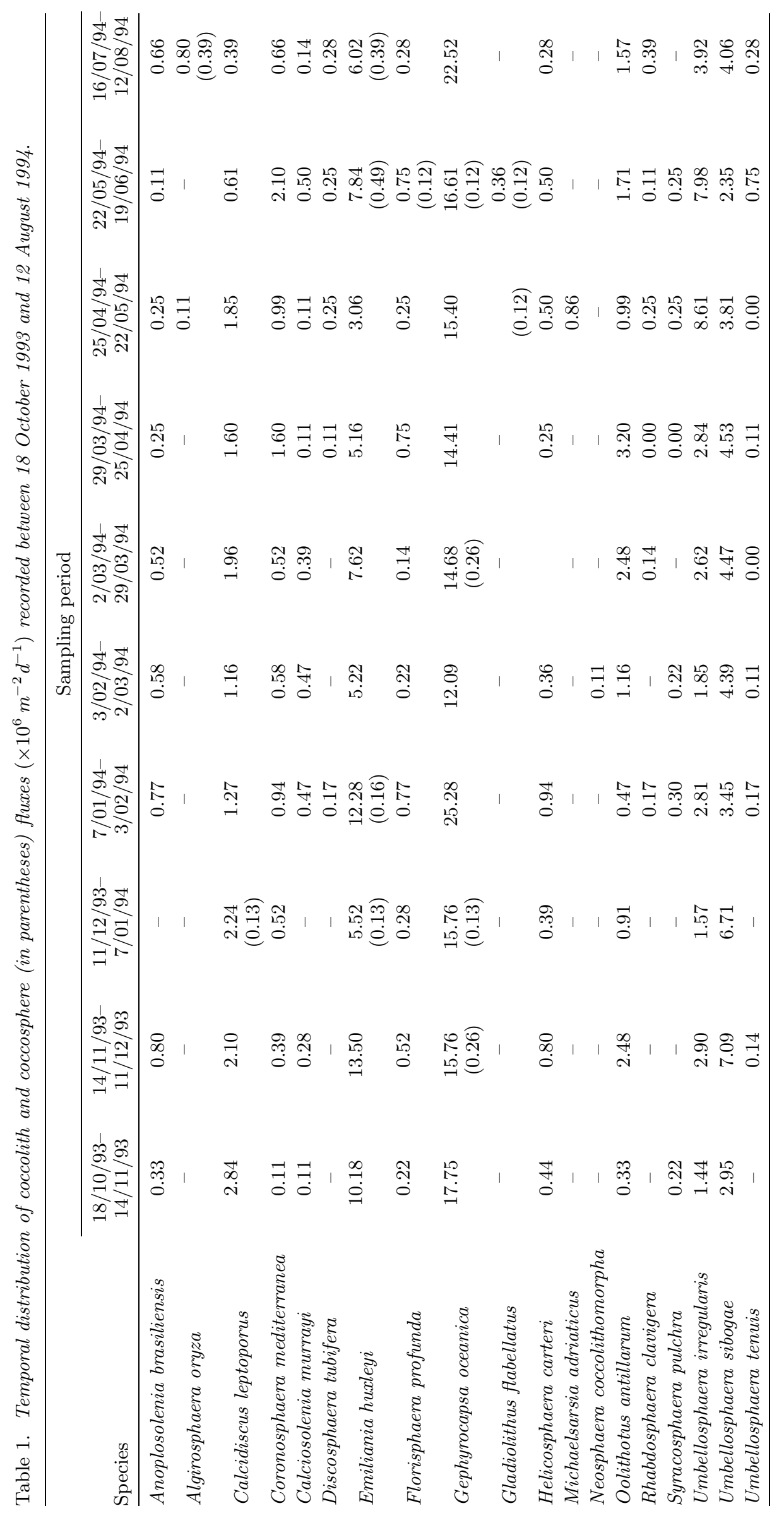


Table 2. Taxonomic list of the coccolithophore species recorded in the sediment trap at $1018 m$ water depth at the sediment trap location in the central Arabian Sea.

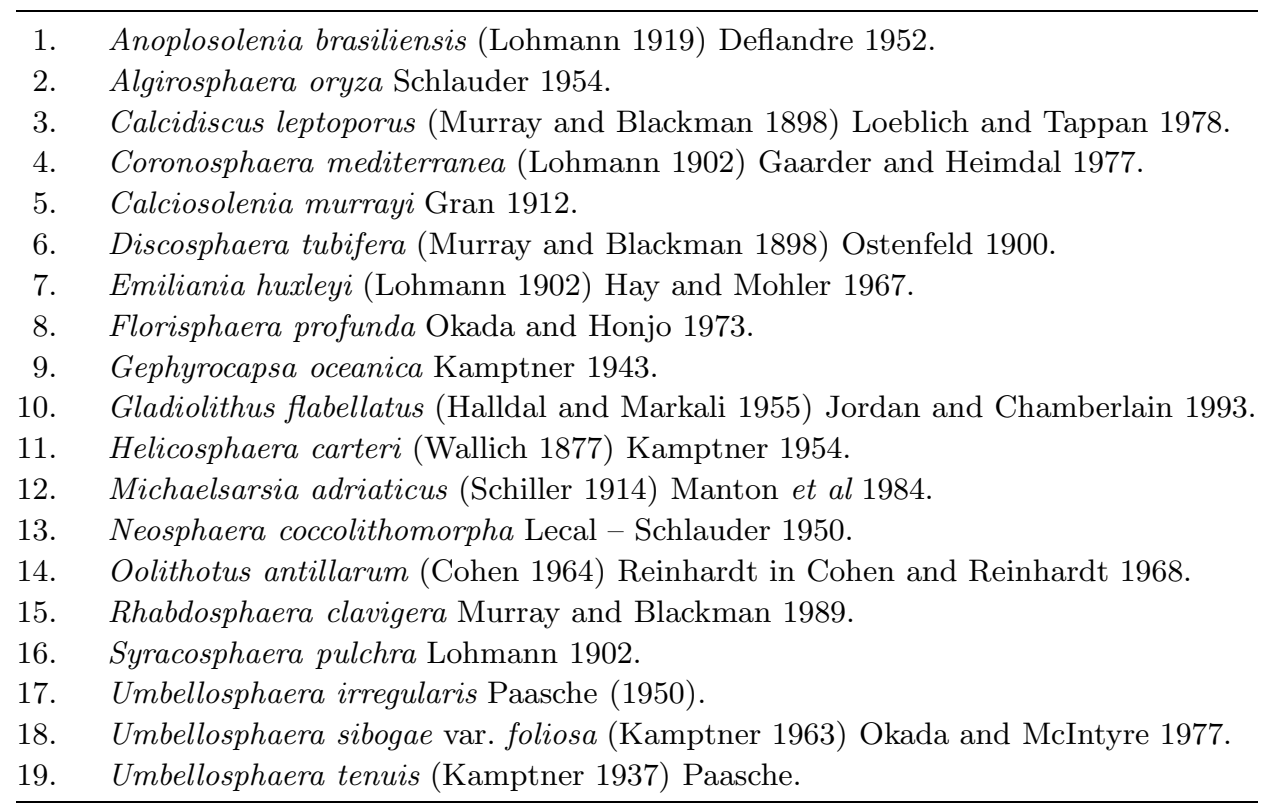

$\left(43.6 \times 10^{6} \mathrm{~m}^{-2} \mathrm{~d}^{-1}\right)$ during early $\mathrm{SW}$ monsoon (22 May-19 June 1994) (figure 2a).

Among the dominant species, $G$. oceanica showed higher flux values $\left(12.1-25.3 \times 10^{6} \mathrm{~m}^{-2} \mathrm{~d}^{-1}\right)$ than E. huxleyi $\left(3.1-13.5 \times 10^{6} \mathrm{~m}^{-2} \mathrm{~d}^{-1}\right)$. The fluxes of $U$. irregularis ranged from 1.4-8.6× $10^{6} \mathrm{~m}^{-2} \mathrm{~d}^{-1}$ with a marginal decrease during SW monsoon (figure $2 \mathrm{a}$ and table 1 ). $U$. sibogae ranged from $2.4-7.1 \times 10^{6} \mathrm{~m}^{-2} \mathrm{~d}^{-1}$ showing higher fluxes during NE monsoon compared to SW monsoon. Fluxes of $F$. profunda ranged from $0.1-0.8 \times 10^{6} \mathrm{~m}^{-2} \mathrm{~d}^{-1}$ while $C$. leptoporus ranged from $0.4-2.8 \times 10^{6} \mathrm{~m}^{-2} \mathrm{~d}^{-1}$ (figure $2 \mathrm{~b}$ and table 1 ).

\section{Discussion}

An examination of mean monthly wind stress curl fields and the associated Ekman pumping velocity at the base of the Ekman layer computed from the Florida State University pseudo wind stress data for the 1993-97 period showed the distinct SWNE orientation of the 'zero' contours of wind stress curl and Ekman pumping velocity from the Somali coast to the Indian coast over the central Arabian Sea (figures are not shown here). The analysis further showed that during October-March (NE monsoon), downwelling (upwelling) occurs to the north (south) of these 'zero' contours covering the northwestern, northern and central Arabian Sea, whereas during June-September (SW monsoon) upwelling (downwelling) occurs to the north (south) of these 'zero' contours aligned with the axis of Findlater Jet. Ekman pumping off Somalia and in the central Arabian Sea forces a strong Summer Monsoon Current (SMC) across western Arabian Sea and central Arabian Sea during SW monsoon (Shankar et al 2002). The Ekman drift (in a thin upper oceanic layer) and the net surface flow (Ekman drift + geostrophic flow) are towards central and western Arabian Sea during NE monsoon and towards southeast in the central Arabian Sea during SW monsoon. Ekman drift and net surface flow would play a major role in the advection of nutrients from northern Arabian Sea (including the Pakistan coast) to central Arabian Sea during NE monsoon and from the Oman coast to central Arabian Sea during SW monsoon (Morrison et al 1998). Thus, it is surmised that the advection of nutrients towards the central Arabian Sea both during SW and NE monsoons would trigger primary productivity in this region and result in the variability of coccolithophores as recorded in the sediment trap samples at greater depth. Maps of satellite derived Sea Surface Temperature (SST) and blended from buoys (moored and drifting) data, for the study period (November 1993, January 1994, May 1994 and July 1994) (Reynolds and Smith 1994) showed intense winter cooling in the northern and western Arabian Sea and the spread of low temperature waters towards central Arabian Sea (closer to the trap location) by January 1994, intense warming in May in the central Arabian Sea, and relatively warmer temperatures south of the Findlater Jet in the central Arabian Sea in July (figure 3a-d). The Simple Ocean Data Assimilation (SODA) Parallel Ocean 


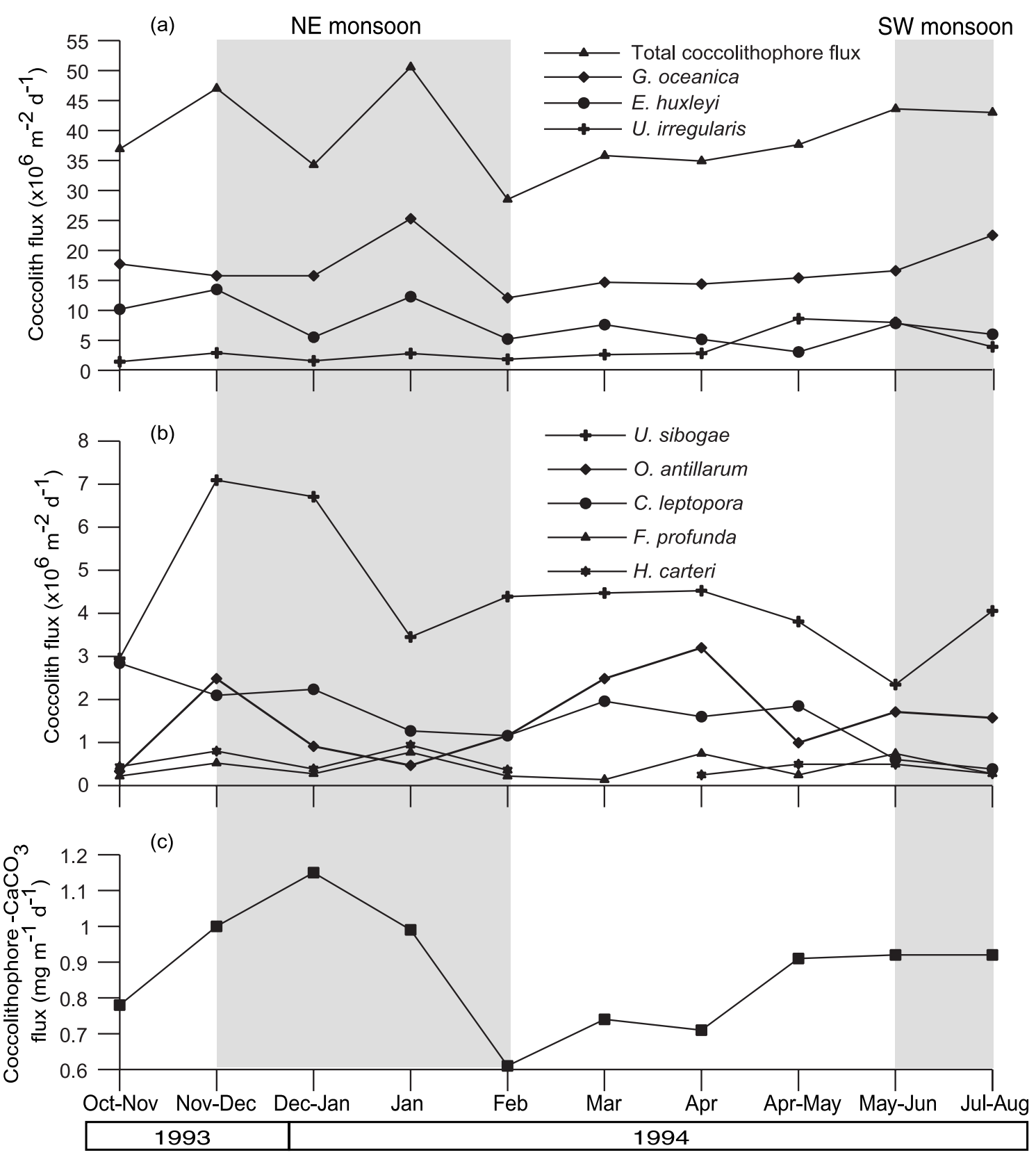

Figure 2. Temporal variation of $(\mathbf{a} \& \mathbf{b})$ total coccolithophore fluxes and fluxes of major individual species of coccoliths $\left(\times 10^{6} \mathrm{~m}^{-2} \mathrm{~d}^{-1}\right)$ and $(\mathbf{c})$ total coccolithophore $-\mathrm{CaCO}_{3}$ fluxes $\left(\mathrm{mgm}^{-2} \mathrm{~d}^{-1}\right)$ between 18 October 1993 and 12 August 1994.

Program (Carton et al 2000) model simulated surface currents during the study period (November 1993, January 1994, May 1994 and July 1994) are similar to ship drifts (figure $2 \mathrm{a}-\mathrm{b}$ ), but less noisy. It may be noted that the model as well as the ship-drifts do not capture some of the meso-scale eddies that are important during the winter monsoon (with reference to this study) as revealed by the altimeter derived sea surface height anomaly data (not shown here). The SODA_POP surface currents suggested that the surface flow emanated from the eastern (western) Arabian Sea towards the central Arabian Sea (figure 4a-d) in January (July), clearly under the influence of seasonal surface winds. The strong eastward flow from the Somalia and Oman coasts during July brings in the nutrient-rich upwelled waters towards central Arabian Sea. Thus, the impacts of seasonally varying wind forcing and the prevailing hydrographic conditions (affecting the nutrient variability and primary production through advection and upwelling/downwelling) in the central Arabian Sea have facilitated the interpretation of the temporal variability of various species of coccolithophores in the following paragraphs. 

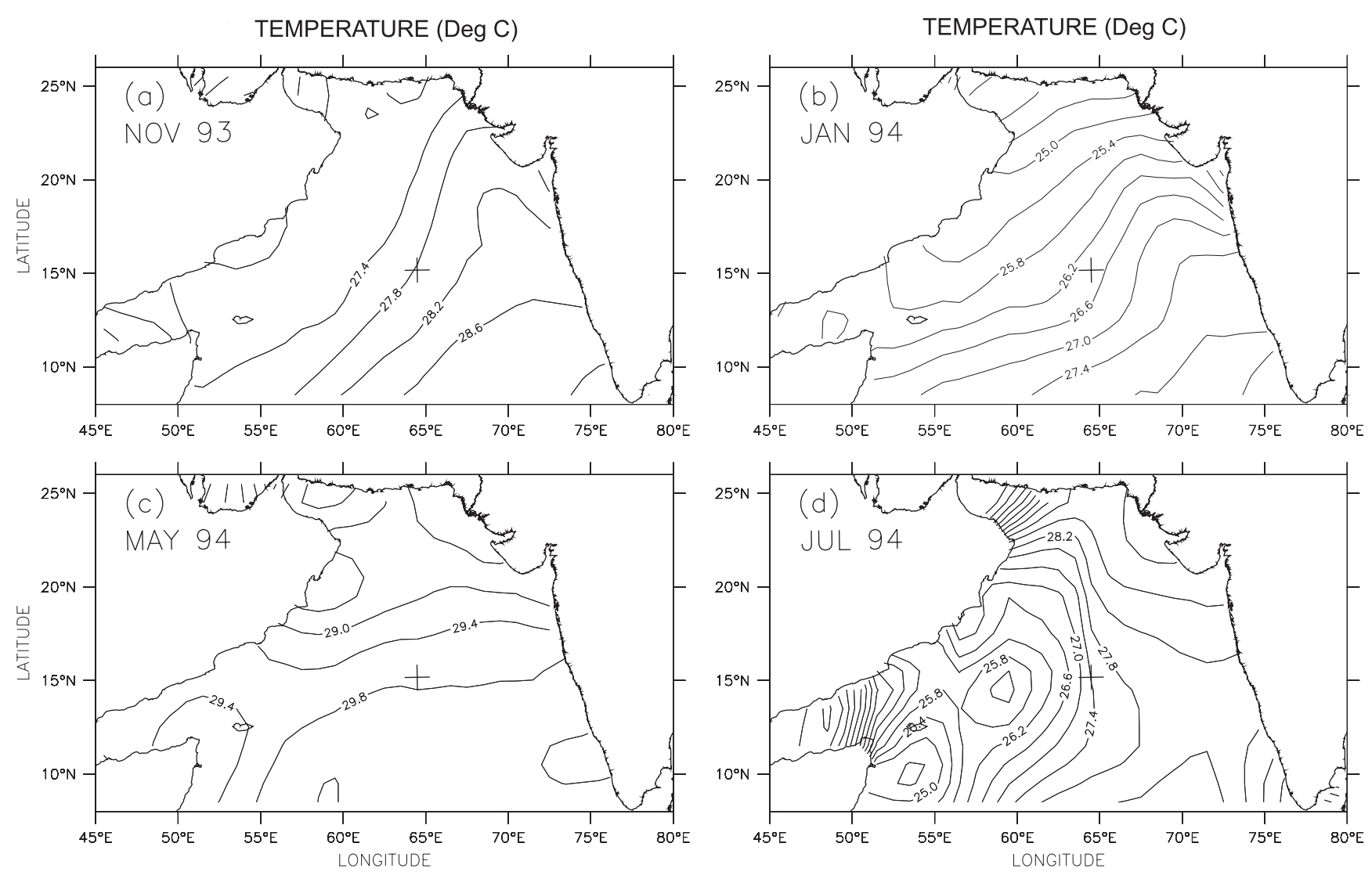

Figure 3. Variation of monthly mean satellite derived Sea Surface Temperature (SST) and blended from buoys (mooring and drifting) data in the Arabian Sea during (a) November 1993, (b) January 1994, (c) May 1994 and (d) July 1994. The sediment trap location is depicted by ' + '.

The present observations showed highest coccolithophore fluxes $\left(>50 \times 10^{6} \mathrm{~m}^{-2} \mathrm{~d}^{-1}\right)$ in the central Arabian Sea during NE monsoon (figure 1 and table 1), which may be attributed to the advection of nutrients (via Ekman drift and surface currents, Shankar et al 2002; figures 4-5) from the northeast Arabian Sea and enhancement of primary production in the central Arabian Sea during NE monsoon. Broerse et al (2000) also reported higher fluxes of coccosphere $\left(2.2 \times 10^{6} \mathrm{~m}^{-2} \mathrm{~d}^{-1}\right)$ and coccoliths $\left(5.9 \times 10^{8} \mathrm{~m}^{-2} \mathrm{~d}^{-1}\right)$ during NE monsoon of 1993 than during SW monsoon of 1992 off Somalia. Andruleit et al (2000) reported higher fluxes off Pakistan shelf during NE monsoon and also at the beginning of SW monsoon. Curry et al (1992) also observed higher abundance of several foraminiferal species at the central Arabian Sea trap location more predominantly during NE monsoon rather than during SW monsoon.

Relatively lower coccolithophore fluxes (figure 2a and table 1) observed during spring intermonsoon corresponded to the oligotrophic conditions associated with the higher SST (figure 3c) and the lower nutrient concentrations due to thermal stratification in the upper ocean (Morrison et al 1998;
Prasanna Kumar et al 2001b; Prasanna Kumar and Narvekar 2005).

The overall observed fluxes of coccolithophores in the central Arabian Sea were higher during NE monsoon than SW monsoon, yet they were 2 to 5 times lower than those reported off Pakistan by Andruliet et al (2000) and off Somalia by Broerse et al (2000) which could be attributed to the intense upwelling conditions at these coasts during NE monsoon. The observed decrease of coccolithophore fluxes over a shorter duration during 11 December 1993-7 January 1994 (NE monsoon) was attributed to the effect of dissolution (as discussed in section 5.1) as evidenced by the presence of corroded coccoliths.

$G$. oceanica is predominantly a low-latitude species (Okada and McIntyre 1979) and shows a maximum flux during NE monsoon (7 January3 February 1994) (figure 2a) due to availability of nutrients as mentioned above. Similarly, the lower fluxes seen during the fag end of $\mathrm{NE}$ monsoon (3 February-2 March 1994) could be either due to dissolution resulting from high productivity or due to the depletion of nutrients in the surface layer in association with the waning of winter conditions. 

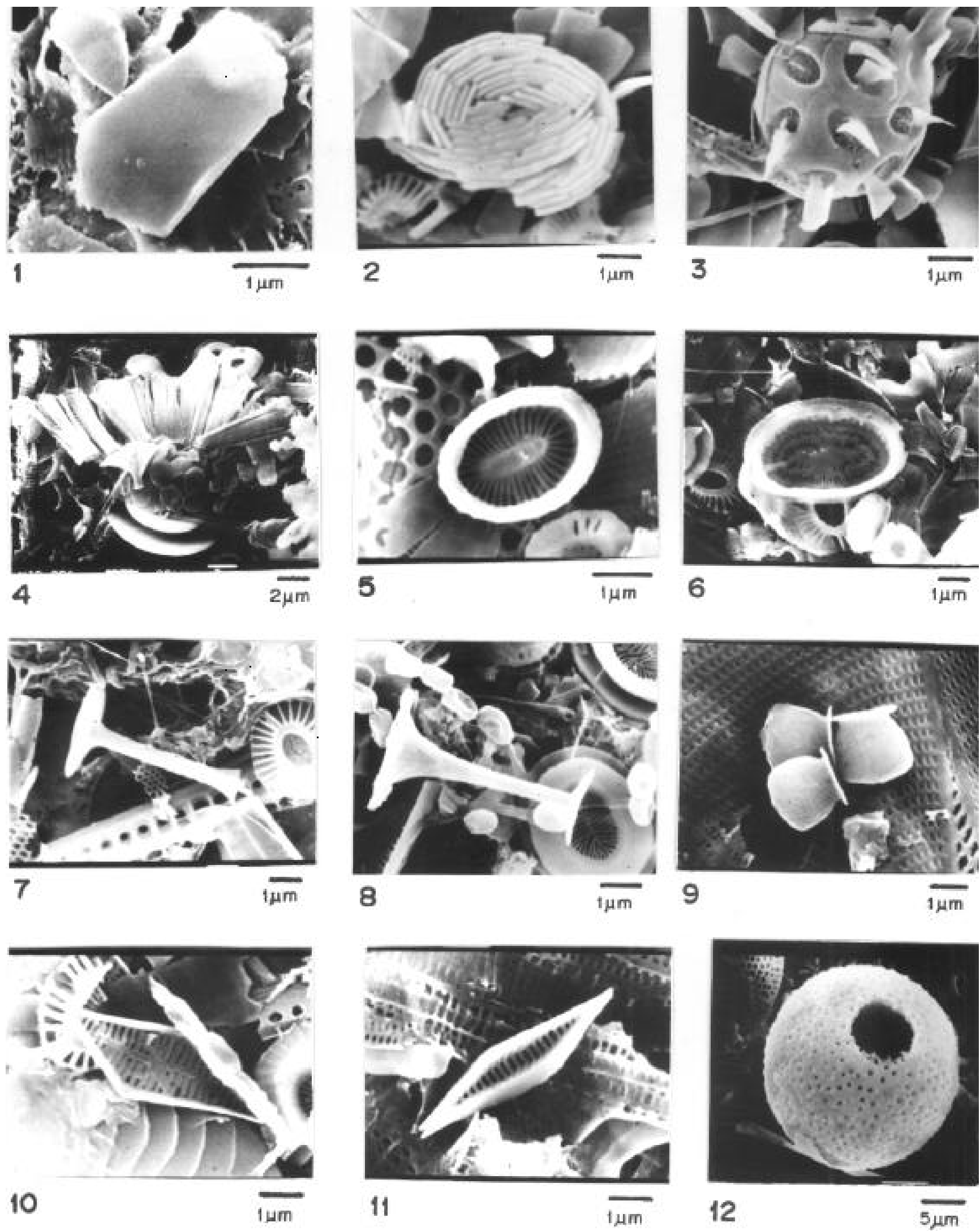

Plate 1. 

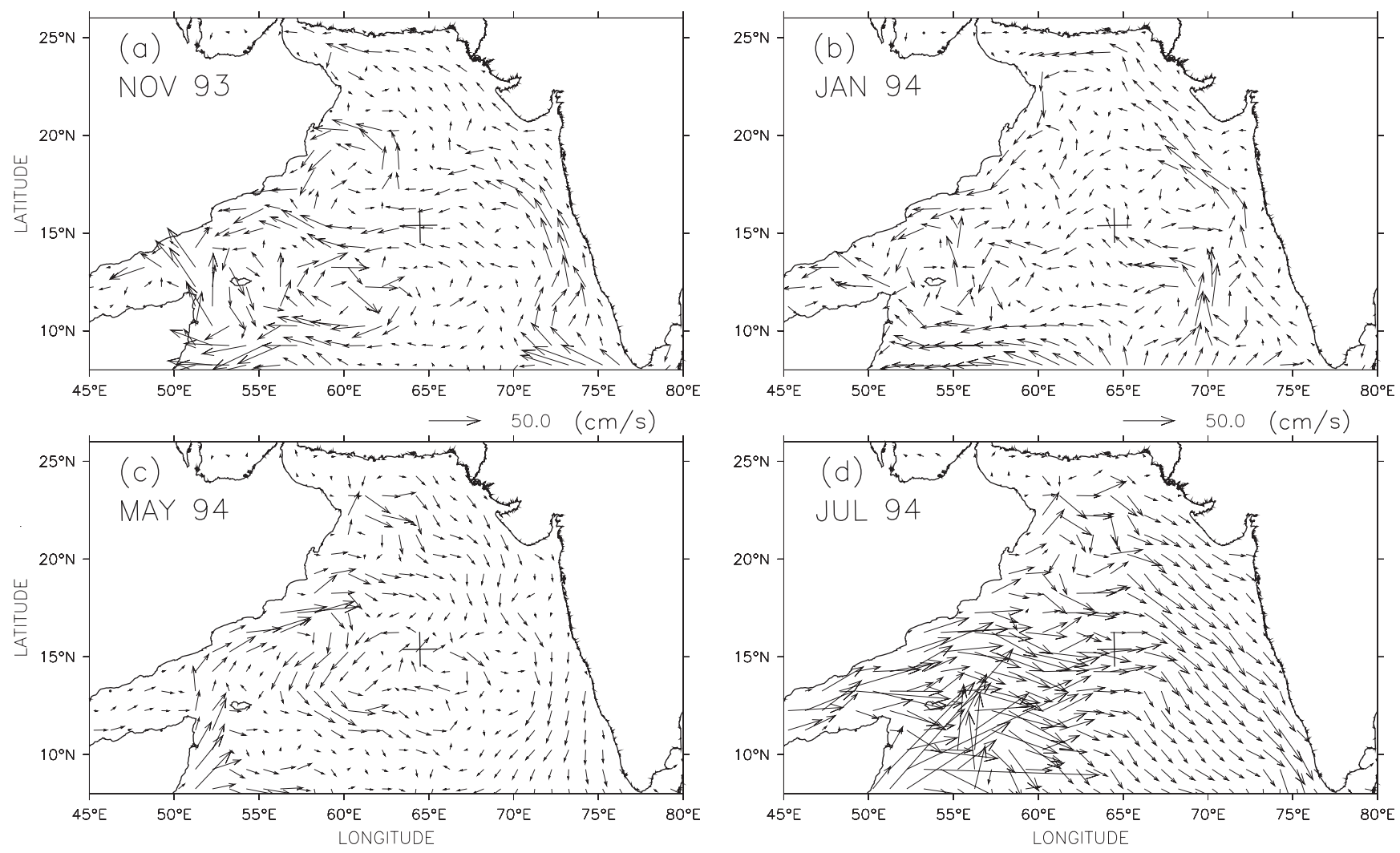

Figure 4. Variation of monthly mean simulated surface currents from Simple Ocean Data Assimilation and Parallel Ocean Program (SODA_POP) [http://www.dsrs.atmos.umd.edu/DATA/SODA_1.4.2] during (a) November 1993, (b) January 1994, (c) May 1994 and (d) July 1994. For clarity alternate grid current vectors are shown. The sediment trap location is depicted by '+'.

Temporal variation of $G$. oceanica and the total coccolithophore flux displayed the same trends (figure 2a). E. huxleyi is a cosmopolitan species abundant in subtropical and tropical waters $\left(2^{\circ}-30^{\circ} \mathrm{C}\right)$ occurring over a wide range of salinities (16-45) (Okada and McIntyre 1977). E. huxleyi also showed a similar trend as that of total coccolithophore fluxes only from 18 October 1993 to 29 March 1994. The lower fluxes of this species during the early
SW monsoon (25 April-22 May 1994) might be due to shallow mixed layer depth associated with the thermal stratification of the upper ocean layer (Prasanna Kumar and Narvekar 2005). G. oceanica and E. huxleyi were widely reported to be the two common coccolith species in the world's ocean at low- to mid-latitudes (McIntyre and Bé 1967; Roth and Coulbourn 1982). These two species were reported as dominant from the northern Indian

\section{Plate 1 caption}

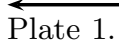

1. Florisphaera profunda, single coccolith (7 January-3 February 1994).

2. Florisphaera profunda, coccosphere (14 November-11 December 1993).

3. Gephyrocapsa ? sp. (Kleijne 1993) (16 July-12 August 1994).

4. Gladiolithus flabellatus, collapsed coccosphere (25 April-22 May 1994).

5. Coronosphaera mediterranea, distal view of coccolith (16 July-12 August 1994).

6. Syracosphaera pulchra, distal view of coccolith (16 July-12 August 1994).

7. Rhabdosphaera clavigera, isolated coccolith (16 July-12 August 1994).

8. Discosphaera tubifera, isolated coccolith (16 July-12 August 1994).

9. Algirosphaera oryza, isolated coccoliths (16 July-12 August 1994).

10. Anoplosolenia brasiliensis, distal view of ordinary coccolith (16 July-12 August 1994).

11. Anoplosolenia brasiliensis, distal view of apical coccolith (16 July-12 August 1994).

12. Thoracosphaera heimii (18 October-14 November 1993). 

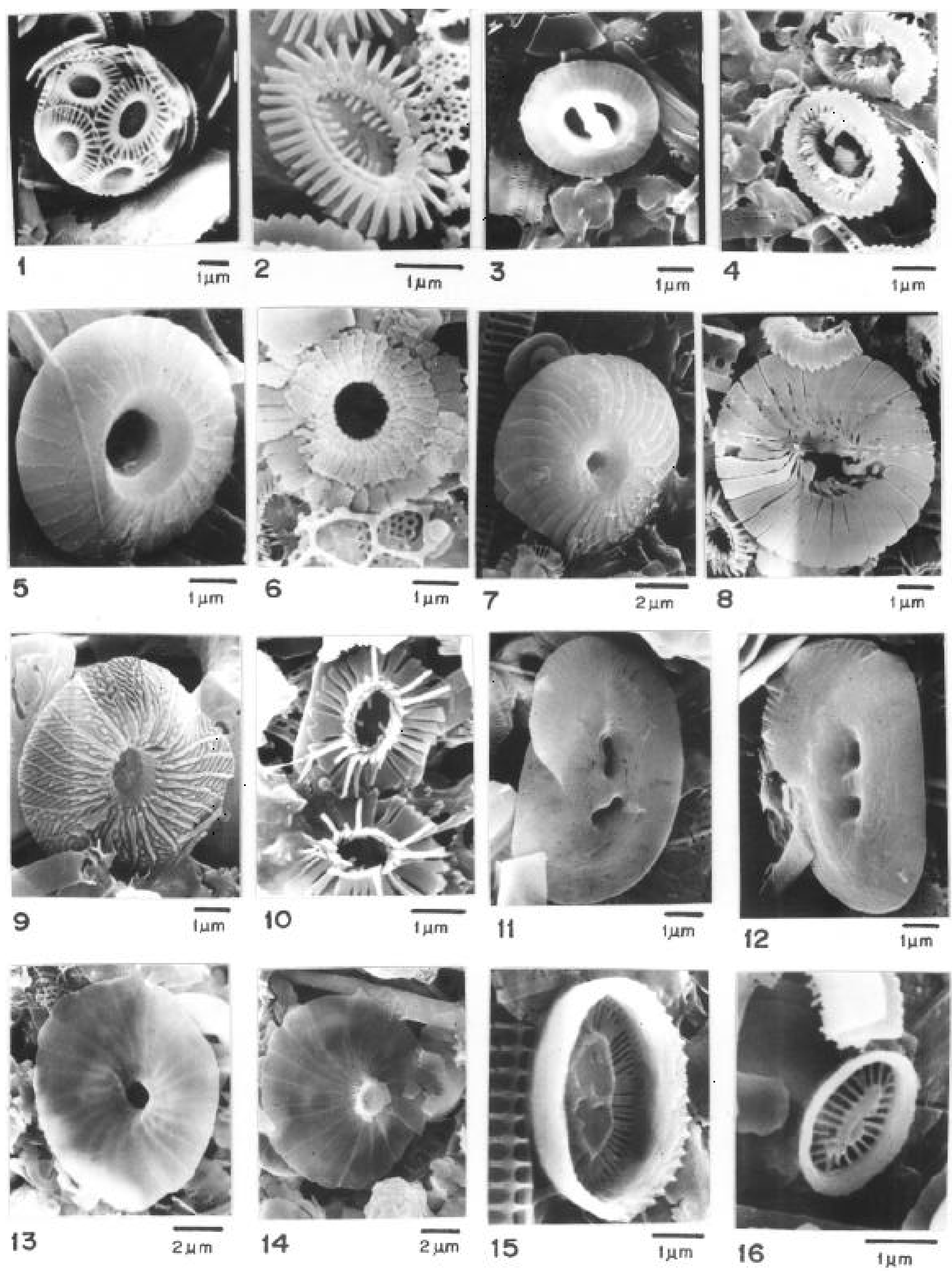

Plate 2. 
Ocean by Kleijne (1993), Houghton and Guptha (1991) and Andruleit and Rogalla (2002) and are known to respond positively to nutrient enrichment by increasing their population both in the ocean as well as in culture. Zeltner (1998) reported maximum coccolithophore fluxes during upwelling relaxation period with $G$. oceanica and E. huxleyi as dominant species in the central Arabian Sea sediment trap location $\left(\mathrm{CAST}, 14^{\circ} \mathrm{N}, 64^{\circ} \mathrm{E}\right)$, which is in close agreement with the present work. Compared to E. huxleyi, G. oceanica is the dominant coccolithophore in the monsoon dominated marginal seas of the western Pacific and in open seas and on continental shelves of the northern and equatorial Indian Ocean (Kleijne 1993; Houghton and Guptha 1991). Broerse et al (2000) explained the dominance of $G$. oceanica over E. huxleyi by its preference for elevated nutrient levels. It was reported that G. oceanica and E. huxleyi do respond to nutrient enrichment in the equatorial and coastal upwelling areas and over continental shelves (Hulburt 1983; Mitchell-Innes and Winter 1987; Kleijne 1993; Houghton and Guptha 1991; Giraudeau et al 1993).

$F$. profunda is another ecologically important species which dwells in the lower photic zone of nutricline and plays a key role as an indicator of past productivity and upwelling (Ahagon et al 1993; Guptha et al 2005) and can also record a change in the nutricline (Molfino and McIntyre 1990). During the study period, fluxes of $F$. profunda varied over a smaller range between 0.1 and $0.8 \times 10^{6} \mathrm{~m}^{-2} \mathrm{~d}^{-1}$, with an average flux of $0.4 \times 10^{6} \mathrm{~m}^{-2} \mathrm{~d}^{-1}$. However, the fluxes of $F$. profunda showed a sharp increase (two times of its mean flux) on 3 occasions during January, April and June, when relatively higher nutrient concentrations were available in the euphotic zone in the study area (Prasanna Kumar and Narvekar 2005).

C. leptoporus is one of the eurythermal species and widely distributed from equatorial to polar waters (McIntyre and Bé 1967). These authors reported higher abundance of $C$. leptoporus during NE monsoon compared to those during SW monsoon. In the present study, the maximum fluxes of this species were observed during 18 October14 November 1993, NE monsoon of 1993 and spring intermonsoon of 1994 . The lowest values recorded during 3 February-2 March 1994 might be attributed to dissolution. Ziveri et al (2000) also reported dissolution of this species from the sinking assemblages to the surface sediments in the northeastern Atlantic.

$U$. sibogae, which prefers nutrient rich upwelled waters displayed higher fluxes during NE monsoon due to advection of these waters from the Pakistan coast towards the central Arabian Sea, which is in agreement with that reported by Broerse et al (2000). However, during SW monsoon, the fluxes of $U$. sibogae were less due to the downwelling process in the central Arabian Sea (south of the Findlater Jet axis).

$U$. irregularis is one of the most common species often reported from tropical waters and its distribution is limited to water temperatures between $21^{\circ}$ and $28^{\circ} \mathrm{C}$ (McIntyre and Bé 1967). It acts as an indicator of oligotrophic conditions (Nishida 1979; Okada and McIntyre 1979; Klejne 1993; Young 1994; Sprengel et al 2000). In the present study, $U$. irregularis showed a peak during spring intermonsoon (25 April-22 May 1994) due to prevailing oligotrophic conditions (higher SSTs (figure 3c) and nutrient poor waters, Prasanna Kumar

\section{Plate 2 caption}

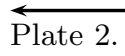

1. Emiliania huxleyi, intact coccosphere (16 July-12 August 1994).

2. Emiliania huxleyi, distal view of coccolith showing dissolution (7 January-3 February 1994).

3. Gephyrocapsa oeanica, distal view of coccolith (16 July-12 August 1994).

4. Gephyrocapsa oeanica, coccoliths showing intense dissolution (7 January-3 February 1994).

5. Umbilicosphaera sibogae, distal view of coccolith (14 November-11 December 1993).

6. Umbilicosphaera sibogae, coccolith showing intense dissolution (7 January-3 February 1994).

7. Calcidiscus leptoporus, distal view of the coccolith (16 July-12 August 1994).

8. Calcidiscus leptoporus, coccolith showing intense dissolution (7 January-3 February 1994).

9. Umbellosphaera tenuis, distal view of the coccolith (2 March-29 March 1994).

10. Umbellosphaera tenuis, coccolith showing intense dissolution (7 January-3 February 1994).

11. Helicosphaera carteri, distal view of the coccolith (7 January-3 February 1994).

12. Helicosphaera carteri, coccolith showing signs of dissolution (16 July-12 August 1994).

13. Umbellosphaera irregularis, distal view of the coccolith (14 November-11 December 1993).

14. Umbellosphaera irregularis, proximal view of the coccolith (14 November-11 December 1993).

15. Coronosphaera mediterranea, distal view of the coccolith (7 January-3 February 1994).

16. Michaelsarsia adriaticus, single detached coccolith (16 July-12 August 1994). 
and Narvekar 2005). This is followed by a decrease in its flux at the onset of SW monsoon with the onset of upwelling. Kleijne (1993) also reported that the $U$. irregularis showed negative correlation with upwelling conditions indicating its preference to oligotrophic conditions in the northern Indian Ocean. Furthermore, Kleijne (1993) also showed dominance of $U$. irregularis in warm oligotrophic conditions in the Gulf of Aden and the Red Sea during summer (June to July). Thus, the observed very low abundance of $U$. irregularis during NE monsoon (figure 2a) and its increase during spring intermonsoon supported its preference to oligotrophic waters in the central Arabian Sea.

\subsection{Dissolution effect}

Dissolution effect, as observed from the corroded coccolithophores, was prominent among the coccoliths such as E. huxleyi, G. oceanica, C. leptopora and $U$. tenuis only during NE monsoon (11 December 1993-3 March 1994). Interestingly, higher intensity of dissolution was noticed during 7 January-3 February 1994, when E. huxleyi, G. oceanica, C. leptopora and the total coccolithophore fluxes exhibited higher fluxes (figure 2a). As explained in the earlier paragraphs, the availability of nutrients and the associated enhancement in primary productivity might be the primary cause for the observed dissolution. It was generally believed that $\mathrm{pH}$ of the waters would decrease with the increased productivity, and would lead to dissolution of the coccolithophores. Supporting evidence could not be provided due to lack of observations in the study area. In view of the fact that the observed assemblages were a mixture of both corroded and intact coccoslithophores, their slow settling velocities facilitate longer exposure to the corrosive waters leading to dissolution. The alternate source of the corroded coccolithophores might also be from the upwelling regions (Pakistan coast), from where the corroded coccolithophores advected towards the study area. Unlike the Bay of Bengal, the ballast theory of settling particles might not be pertinent to the central Arabian Sea, as it does not experience any terrigeneous fluxes that would have otherwise helped for particle settling at a faster rate. Study of coccolithophore fluxes by Broerse et al (2000) shows that the preservation of coccoliths strongly depends on rapid transport for protection from corrosive water masses. They can resist dissolution by getting incorporated with fecal pellets and other oceanic macro-aggregates that are responsible for the rapid vertical transport to the sea floor. Samtleben and Bickert (1990) reported a similar finding in sediment trap samples from the subarctic Atlantic, the Lofoten basin. Andruleit
(2000) reported dissolution of Coccolithus pelagicus, while other species in the same samples did not show dissolution. From these observations he concluded that dissolution did not take place during or after entrapment of the coccolith assemblages, hence they must have originated from different source areas or have experienced different settling conditions. Owing to the differential dissolution of coccolithophores, a supply of corroded forms by advection cannot be ruled out, if they sink slowly. Milliman et al (1999) documented an increasing amount of evidence to suggest considerable dissolution of calcium carbonate well above the chemical lysocline and concludes that biologically mediated processes might be responsible for dissolution. In this study, we believe that the observed dissolution during NE monsoon was a biologically mediated phenomenon caused by enhanced productivity during this period. Recently, Guptha et al (2004) have also reported dissolution in the photic zone in the equatorial Indian Ocean.

\subsection{Coccolithophore $\mathrm{CaCO}_{3}$ fluxes in the central Arabian Sea}

The coccolithophore $\mathrm{CaCO}_{3}$ flux was computed by multiplying the flux values of various species with their average coccolith weight (taken from Broerse et al 2000 and others). Thus, the estimated coccolithophore $\mathrm{CaCO}_{3}$ flux ranged from 0.6 to $1.2 \mathrm{mg} \mathrm{m}^{-2} \mathrm{~d}^{-1}$. High values of $\mathrm{CaCO}_{3}$ $\left(1.2 \mathrm{mg} \mathrm{m}^{-2} \mathrm{~d}^{-1}\right)$ were observed during NE monsoon (11 December 1993-7 January 1994), followed by a minimum value of $0.6 \mathrm{mg} \mathrm{m}^{-2} \mathrm{~d}^{-1}$ during the fag end of NE monsoon (3 February-2 March 1994) and showed a marginal increase during early SW monsoon. Broerse et al (2000) reported $8.1 \mathrm{mg} \mathrm{m}^{-2} \mathrm{~d}^{-1}$ as the mean yearly estimated coccolithophore- $\mathrm{CaCO}_{3}$ flux (both loose coccolith and coccosphere) off Somalia in the western Arabian Sea. Furthermore, they also stated that the coccolithophore contribution to the total $\mathrm{CaCO}_{3}$ flux (calcareous microfossils) was higher during the early SW monsoon period.

\section{Conclusions}

This study of coccolithophore fluxes from the sediment trap samples in the central Arabian Sea, in general, showed enhanced fluxes during NE monsoon compared to SW monsoon. The advection of nutrient-rich waters from the upwelling regions in the northeast Arabian Sea to the central Arabian Sea by the prevailing Ekman drift and surface currents during NE monsoon and enhancement of primary productivity in the central Arabian Sea might be primary cause for the observed 
higher fluxes during the winter season. Similarly, the relatively lower coccolithophore fluxes during SW monsoon were attributed to downwelling (or absence of upwelling) to the south of Findlater Jet axis where the sediment trap was located. $G$. oceanica was by far the most abundant during NE monsoon emphasizing the influence of northern Arabian Sea nutrient rich waters in winter season. E. huxleyi and F. profunda showed higher fluxes during NE monsoon and lower fluxes during SW monsoon suggesting the impact of the abovementioned seasonally varying influence of physical forcing. $U$. irregularis showed higher fluxes during spring intermonsoon, when the availability of nutrients was low in the upper layer, confirming its preference for oligottophic conditions. C. leptoporus and $U$. sibogae also showed seasonal variation with higher values during $\mathrm{NE}$ monsoon and low values during SW monsoon. On the contrary, C. mediterranea showed lower fluxes during NE monsoon and higher fluxes during spring intermonsoon, demonstrating their preference to low nutrients and higher temperature. This study clearly displays the variation of coccolithophore fluxes with the seasonally changing physical forcing over the central Arabian Sea.

\section{Acknowledgements}

We thank the Director, National Institute of Oceanography, for encouragement and support in this study. We are indebted to the Department of Ocean Development (DOD), New Delhi for providing the research vessel and the Captain and crew onboard ORV Sagar Kanya for their help and cooperation during the sediment trap mooring operations. We thank Mr Umesh Shirsat, Mr Areef Sardar and Mr Vijay Khedekar for their assistance in the SEM analysis. Mr S Muralikrishna and Mr A Raju helped in the preparation of the monthly maps of satellite derived parameters. One of the authors (L P M) thanks the Council of Scientific and Industrial Research (CSIR), New Delhi for the Fellowship. One of authors (RM) is grateful to the Director, National Centre for Antarctic \& Ocean Research, Goa for constant help and encouragement. The project is funded by Department of Science and Technology New Delhi vide no. ESS/23/VES/124/2001. The authors thank the anonymous reviewers for their critical comments that improved the quality of this paper. This is N.I.O. contribution no. 4123.

\section{References}

Ahagon N, Tanaka Y and Ujiié H 1993 Florisphaera profunda, a possible nannoplankton Indicator of late
Quaternary changes in seawater turbidity at the northwestern margin of the Pacific; Mar. Micropaleontol. 22 255-273.

Andruleit H 2000 Dissolution-affected coccolithophore fluxes in the central Greenland Sea (1994/95); Deep-Sea Res. II 47 1719-1742.

Andruleit H and Rogalla U 2002 Coccolithophores in surface sediments of the Arabian Sea in relation to environmental gradients in surface waters; Mar. Geol. 186 505-256.

Andruleit H, von Rad U, Bruns A and Ittekkot V 2000 Coccolithophore fluxes from sediment traps in the northeastern Arabian Sea off Pakistan; Mar. Micropaleontol. 38 285-308.

Andruleit H, Stäger S, Rogalla U and Čepek P 2003 Living coccolithophores in the northern Arabian Sea: ecological tolerance and environmental control; Mar. Micropaleontol. 49 157-181.

Brand L E 1994 Physiological ecology of marine coccolithophores; In: Coccolithophores (eds) Winter A and Siesser W G (Cambridge: Cambridge University Press), pp. 39-49.

Broerse A T C, Brummer G-J A and van Hinte J E 2000 Coccolithophore export production in response to monsoonal upwelling off Somalia (northwestern Indian Ocean); Deep-Sea Res. II 47 2179-2205.

Carton J, Chepurin G, Cao X and Giese B 2000 A simple ocean data assimilation analysis of the global upper ocean 1950-95. Part I: Method; J. Phys. Oceanogr. 30 294-309.

Curry W B, Ostermann D R, Guptha M V S and Ittekkot V 1992 Foraminiferal production and monsoon upwelling in the Arabian Sea: Evidence from sediment traps; In: Upwelling Systems: Evolution since the Miocene (eds) Smmerhayes C P, Prell W L and Emeis K C (Geological Society Special Publication No. 64), pp. 93-106.

Findlater J 1969 A major low-level air current near the Indian Ocean during the northern Summer; Quart. J. Roy. Meteor. Soc. 95 362-380.

Flagg C N and Kim H 1998 Upper ocean currents in the northern Arabian Sea from shipboard ADCP measurements collected during the 1994-1996 U.S. JGOFS and ONR programs; Deep-Sea Res. II 45 1917-1959.

Giraudeau J, Monteiro M S and Nikodemus K 1993 Distribution and malformation of living coccolithophores in the northern Benguela upwelling system off Namibia; Mar. Micropaleontol. 22 93-110.

Guptha M V S, Mohan R and Muralinath A S 1995 Living coccolithophorids from the Arabian Sea; Rivista Italiana Paleontologia et Stratigrafia 100(4) 551-574.

Guptha M V S, Mergulhao L and Murty V S N 2004 On the occurrence of corroded coccolithophores in the water column. In the abstract volume of the National Symposium on Application of Marine Geosciences held at NIO, Goa, from 19-20 February, 2004.

Guptha M V S, Mergulhao L P, Murty V S N and Shenoy D M 2005 Living coccolithophores during the northeast monsoon from the Equatorial Indian Ocean: Implications on hydrography; Deep-Sea Res. II $\mathbf{5 2}$ 2048-2060.

Honjo S 1975 Dissolution of suspended coccoliths in the deep-sea water column and sedimentation of coccolith ooze; In: Dissolution of Deep-Sea Carbonates (eds) Sliter W B, Bé A W H and Berger W H (Cushman Found Foraminiferal Research Special Publication, No. 13), pp. 115-128.

Honjo S 1980 Material fluxes and modes of sedimentation in the mesopelagic and bathypelagic zones; J. Mar. Res. 38 53-97.

Houghton S D and Guptha M V S 1991 Monsoonal and fertility controls on recent marginal sea and continental 
shelf coccolith assemblages from the western Pacific and northern Indian oceans; Mar. Geol. 97 251-259.

Hulburt E M 1983 Quasi K-selected species, equivalence, and the oceanic coccolithophorid plankton; Bull. Mar. Sci. 33 197-212.

Kleijne A 1993 Morphology, Taxonomy and Distribution of Extant Coccolithophorids (Calcareous Nannoplankton); $\mathrm{PhD}$ thesis, Amstermdam Free University.

Madhupratap M, Prasanna Kumar S, Bhattathiri P M A, Kumar M D, Raghukumar S, Nair K K C, Ramaiah N 1996 Mechanism of the biological response to winter cooling in the northeastern Arabian Sea; Nature 384 549-552.

Manghnani V, Morrion J M, Hopkins T S and Bohm E 1998 Advection of upwelled waters in the form of plumes off Oman during the Southwest monsoon; Deep-Sea Res. II 45 2027-2052.

Mariano A J, Ryan E H, Perkins B D and Smithers S 1995 The Mariano Global Surface Velocity Analysis 1.0; Technical Report No. CG-D-34-95, US Department of Transportation, United States Coast Guard, Office of Engineering, Logistics, and Development, Washington DC 20593-0001.

McIntyre A and Bé A W H 1967 Modern coccolithophores of the Atlantic Ocean. I. Placoliths and cyrtoliths; DeepSea Res. 14 561-597.

Milliman J D, Troy P J, Balch W M, Adams A K, Li Y-H and Mackenzie F T 1999 Biologically mediated dissolution of calcium carbonate above the chemical lysocline?; Deep-Sea Res. I 46 1653-1669.

Mitchell-Innes B A and Winter A 1987 Coccolithophores: a major phytoplankton component in mature upwelled waters off the Cape Peninsula, South Africa in March 1983; Mar. Biol. 95 25-30.

Molfino B and McIntyre A 1990 Precessional forcing of nutricline dynamics in the equatorial Atlantic; Science 249 766-769.

Morrison J M, Codispoti L A, Gaurin S, Jones B, Manghnani V and Zheng Z 1998 Seasonal variation of hydrographic and nutrient fields during the US JGOFS Arabian Sea Process Study: Deep-Sea Res. II 45 2053-2101

Nishida S 1979 Atlas of Pacific nannoplanktons; News Osaka Micropaleontol., Special Paper 3 1-31.

Okada H and McIntyre A 1977 Modern coccolithophores of the Pacific and North Atlantic Oceans; Micropaleontol. 23(1) 1-55.

Okada H and McIntyre A 1979 Seasonal distribution of modern coccolithophores in the western North Atlantic Ocean; Mar. Biol. 54 319-328.

Prasanna Kumar S and Prasad T G 1996 Winter cooling in the Arabian Sea; Curr. Sci. 71(11) 834-841.

Prasanna Kumar S and Narvekar J 2005 Seasonal variability of mixed layer in the central Arabian Sea and its implication on nutrients and primary productivity; Deep-Sea Res. II 52 1848-1861.

Prasanna Kumar S, Madhupratap M, Dileep Kumar M, Gauns M, Muraleedharan P M, Sarma V V S S and De Souza S N 2000 Physical control of primary productivity on a seasonal scale in central and eastern Arabian Sea; Proc. Indian Acad. Sci. (Earth Planet. Sci.) 109 433-441.

Prasanna Kumar S, Ramaiah N, Gauns M, Sarma V V S S, Muraleedharan P M, Raghukumar S, Dileep Kumar M and Madhupratap M 2001a Physical forcing of biological productivity in the northern Arabian Sea during the northeast monsoon; Deep-Sea Res. II 81 561-597.

Prasanna Kumar S, Madhupratap M, Dileep Kumar M, Muraleedharan P M, De Souza S N, Mangesh G and Sarma V V S S 2001b High biological productivity in the central Arabian Sea during the summer monsoon driven by Ekman pumping and lateral advection; Curr. Sci. $\mathbf{8 1}$ 1633-1638.

Qasim S Z 1982 Oceanography of the northern Arabian Sea; Deep-Sea Res. 29 1041-1068.

Reynolds R W and Smith T M 1994 Improved global sea surface temperature analysis using optimum interpolation; J. Climate 7 929-948.

Roth P H and Coulbourn W T 1982 Floral and solution patterns of coccolith in surface sediments of the North Pacific; Mar. Micropaleontol. 7 1-52.

Samtleben C and Bickert T 1990 Coccoliths from the Norwegian Sea; Mar. Micropaleontol. 16 39-64.

Schiebel R, Zeltner A, Treppke U F, Waniek J J, Bollmann J, Rixen T and Hemleben C 2004 Distribution of diatoms, coccolithophores and planktic foraminifers along a trophic gradient during SW monsoon in the Arabian Sea; Mar. Micropaleontol. 51 345-371.

Shankar D, Vinayachandran P N, Unnikrishnan A S 2002 The monsoon currents in the north Indian Ocean; Progr. Oceanogr. 52 63-120.

Smith S I, Banse K, Cochran J K, Codispoti L A, Ducklow H W, Luther M E, Olson D B, Peterson W T, Prell W L, Surgi N, Swallow J C and Wishner K (eds) 1991 U.S. JGOFS: Arabian Sea process study, U.S. Planning Report edn, Vol. 13. Woods Hole Oceanographic Institution, Woods Hole, Massachusetts, 164 pp.

Smith S I, Codispoti L A, Morrison J M, Barber R T 1998 The 1994-1996 Arabian Sea Expedition: an integrated, interdisciplinary investigation of the response of the north western Indian Ocean monsoonal forcing; DeepSea Res. II 45 1905-1916.

Sprengel C, Baumann K and Neuer S 2000 Seasonal and interannual variations of coccolithophore fluxes and species compositions in sediment traps north of Gran Canaria; Mar. Micropaleontol. 39 157-178.

Steinmetz J C 1994 Sedimentation of coccolithophores; In: Coccolithophores (eds) Winter A and Siesser W G (Cambridge: Cambridge University Press), pp. 179-197.

Waniek J, Koeve W and Prien R D 2000 Trajectories of sinking particles and the catchment areas above sediment traps in the northeast Atlantic; J. Mar. Res. 58 983-1006.

Westbroek P, Brown C W, van Bleijswijk J, Brownlee C, Brummer G J, Conte M, Egge J, Fernandéz E, Jordan R, Knappertsbusch M, Stefels J, Veldhuis M, van der Wal P and Young J R 1993 A model system approach to biological climate forcing: The example of Emiliania huxleyi; Global Planet. Change 8 27-46.

Wyrtki K 1973 Physical oceanography of the Indian Ocean; In: The Biology of the Indian Ocean (ed.) Zeitzschel B (New York: Springer-Verlag) pp. 18-36.

Young J 1994 Function of coccoliths; In: Coccolithophores (eds) Winter A and Siesser W G (Cambridge: Cambridge University Press), pp. 63-82.

Zeltner A 1998 Coccolith fluxes in the central Arabian Sea; Seventh International Nannoplankton Association, La Parguera, Puerto Rico, Abstract.

Ziveri P, Broerse A C, Hinte J E van and Honjo S 2000 The fate of coccoliths at $48^{\circ} \mathrm{N} 21^{\circ} \mathrm{W}$, northeastern Atlantic; Deep-Sea Res. II 47 1853-1875. 